Journal of Fisheries International 6(2): 36-40, 2011

ISSN: 1817-3381

(C) Medwell Journals, 2011

\title{
Effect of Beach Seine Height and Mesh Size on Catch Characteristics in the Southern Part of the Caspian Sea
}

\author{
${ }^{1}$ Seyed Aminollah Taghavi Motlagh, ${ }^{2}$ Saeed Gorgin, ${ }^{3}$ Hasan Fazli and ${ }^{4}$ Shahram Abdolmaleki \\ ${ }^{1}$ Iranian Fisheries Research Organization, Tehran, Iran \\ ${ }^{2}$ Department of Fisheries, College of Natural Resources and Marine Sciences, \\ Tarbiat Modaress University, Mazandaran, Iran \\ ${ }^{3}$ Research Center of Caspian Sea Ecology, Sari, Iran \\ ${ }^{4}$ Research Center of Inland Waters, Bandar Anzali, Iran
}

\begin{abstract}
In this study, influence of height and mesh size of beach seine net on the amount of fishing, length frequency and species composition of caught fish was examined. Two beach seine nets with 20 and $24 \mathrm{~m}$ heights and each net with 30 and $33 \mathrm{~mm}$ center part mesh size were used by two fishing cooperatives during 2008 and 2009. Rutilus frisii kutum and Mugil auratus were selected as a target fish in this study. Catch and biological data were measured and recorded. Results indicated that the height and mesh sizes used in the present study had significant effect on the catch characteristics in terms of amount of species, catch rates and species composition. Amount of catch was reduced in $24 \mathrm{~m}$ beach seine in comparison with $20 \mathrm{~m}$ height net both in 2008 and 2009. There were significant differences between fish caught by 30 and $33 \mathrm{~mm}$ mesh size net in 2008 and 2009. With an increase in size of mesh net from $30-33 \mathrm{~mm}$, amount of Rutilus frisii kutum catches increased but amount of Mugil auratus catches decreased. There was no any especial effect of height and mesh size on fish length. Amount of bycatch also increased in relation to net height from 20-24 m.
\end{abstract}

$\underline{\text { Key words: Beach seine net, height, mesh size, quantity and quality of fishing, Caspian sea, Iran }}$

\section{INTRODUCTION}

Small-scale fisheries generally contribute about half to the amount of fish consumed directly by humans $(\mathrm{FAO}$, 2003). Fisheries management includes different management measures. Among these are technical regulations on fishing gears in order to obtain the overall goal of high sustainable yield in the fisheries. These are regulations, e.g., on height and mesh size to improve the selective properties of fishing gear so that bycatches of non targeted fish are reduced. There are many types of fishing gear and they all impact the marine environment in different ways and to different degrees. This is why, the same species may have different rankings depending to the gear that was used to catch it. Seining is a fishing technique traditionally done in areas with large schools or groups of fish. The earliest form of seining was drag netting (also called beach seining). There is evidence of seine nets used in artisanal fisheries several thousands of years ago and on every continent (Von Brandt, 1984). This fishing method is an efficient method for scientific purposes that widely used in the study of fish communities along a wide variety of habitats including rivers, estuarine, reservoir and marine habitats with sandy or smooth bottoms (Cailliet et al., 1986; Monteiro-Neto and Musick, 1994; Pierce et al., 1990). The Iranian coast of the Caspian sea contains many suitable areas for fisheries. One of the most important fishing methods in this area is fishing with one kind of beach seine net namely Pareh (Fig. 1). This is a beach seine fishing which in Gabriel classification is a beach seine net without cod end (Gabriel et al., 2005). Setting and hauling of Pareh are as follows; one of the warps of net wings fixed in beach. Then, the net is operated by a single boat to the sea and after 1 or $2 \mathrm{~km}$ the second warp turning back towards the shore in a loop shape and fixed in another point in beach about 400 or $500 \mathrm{~m}$ far away from the 1 st warp. The net will stay for 2 or $4 \mathrm{~h}$ in the sea.

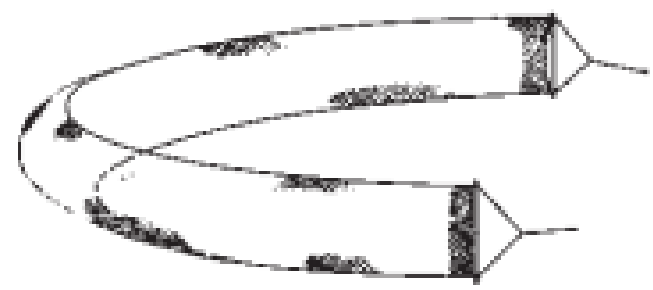

Fig. 1: Beach seine without cod end

Corresponding Author: Seyed Aminollah Taghavi Motlagh, Iranian Fisheries Research Organization, Tehran, Iran 
Then, hauling of the warps begins by two winches. This fishing method specialized for catch of bony fishes that live or move near beaches. There is not any bag in this kind of fishing but center part of the net have smallest mesh size and enough hanging ration which act as a bag part and about $90 \%$ of fishing done with this part. Fishing with Pareh is started in October and closed in April every year. Pareh is made from four parts, one part in center with smallest mesh size and three parts on the left and right sides (Fig. 2). The mesh sizes of the net are different from October to February and from February to April depend on size and kind of target fishes. There is specific length for each part and total length of the net. But height of the net is different from region to another region and it is depended on depth of water. Assessment of fish populations and species assemblages is important in managing fisheries and environmental quality in marine and freshwater systems (Murphy and Willis, 1996; Simon, 1998). There are some investigations that studied biology of caught fishes and based on those studies, mesh size of net and time of fishing were determined (Sayad, 1990; Ghaninejad and Moghim, 1993; Abdolmaleki et al., 2005; Daryanabard et al., 2009). There is not any research that shows effect of net height on fishing amount, length frequency and species diversity of catch fishes in Southern Caspian sea. Therefore, the researchers arranged a research to study effects of this parameter. The purpose of this study was to determine the role of height and central part mesh size in beach seine net to evaluate differences in species composition and length frequency of Rutilus frisii kutum and Mugil auratus caught in the Southern area of the Caspian sea.
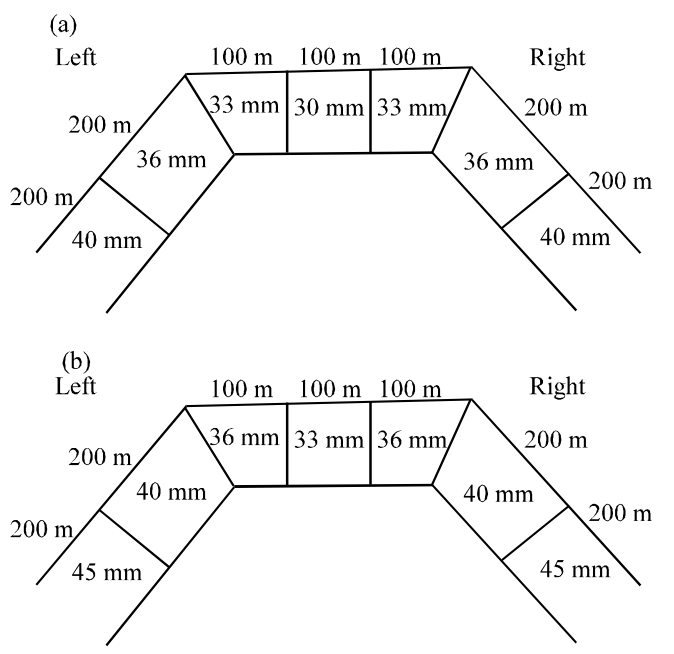

Fig. 2: Shape, mesh size and length of each part of beach seine, Pareh: a) used from October to the end of January and b) used from February to April

\section{MATERIALS AND METHODS}

This experiment was carried out in the coastal fishing area of Mazandaran province, Southern part of the Caspian sea (Fig. 3). Because design and preparing of nets with different height is very expensive and not possible for researchers to do that two fishing cooperatives with two different net heights were selected for the study. Ghoreishi fishing cooperative used a $20 \mathrm{~m}$ height net in 2008. The cooperative then used a net of $24 \mathrm{~m}$ height in 2009. Very closed to this fishing cooperative, Islami fishing cooperative used a net with $20 \mathrm{~m}$ height in both years.

The central part of the net mesh sizes used in the experiments was $30 \mathrm{~mm}$ from October to late January and changed to the net with $33 \mathrm{~mm}$ mesh size from February to April. Therefore, studies were separated into two parts, nets with 20 and $24 \mathrm{~m}$ height and 30 and $33 \mathrm{~mm}$ mesh size in center. These are sizes that fishermen use for fishing in this area and it is based on the size and kind of target fishes. Because two cooperatives were located much closed to each other, environmental factors were the same. Also, other parameters such as depth of the water $(15 \mathrm{~m})$ and length of the net were the same $(1100 \mathrm{~m})$. Therefore, situation of the catch will be focused on the effects of the height net.

Sampling program was arranged during October to April for 2 fishing years (2008 and 2009). Two target fishes, Rutilus frisii kutum and Mugil auratus were selected in this study. Fork length and weight of each fish were measured and recorded. Length frequency of target fishes in two fishing cooperatives was analyzed. For measuring of fish's length a biometry table was used and fork length was estimated.

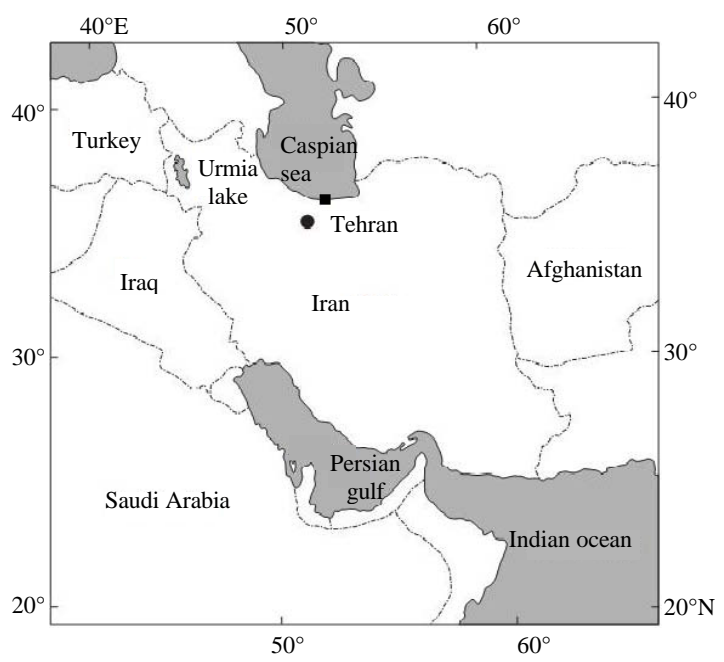

Fig. 3: Location of beach seine sampling site in Southern Caspian sea ( 
Statistics: All of the data were analyzed with Minitab software (Version 15) and Chi-square $\left(\chi^{2}\right)$ test and subsequent differences were considered significant. Data are presented as means $\pm \mathrm{SD}$ of mean.

\section{RESULTS AND DISCUSSION}

Analysis of fishing data revealed some significant differences between Islami and Ghoreishi fishing cooperatives that used beach seine nets (Pareh) with different height and mesh sizes. The amount of Rutilus frisii kutum and Mugil auratus catches differed significantly between the two heights and mesh sizes used. The amounts of fishing for these species are shown in Table 1 and 2. In Islami fishing cooperative that used net with $20 \mathrm{~m}$ height, there were comparable differences between catch data in 2008 and 2009 as the amount of catch increased using $20 \mathrm{~m}$ height net.

In Ghorashi fishing cooperative which used net both with 20 and $24 \mathrm{~m}$ height, amount of catches decreased when this cooperative used $24 \mathrm{~m}$ height net (Table 3 and 4). With an increase in size of mesh from 30-33 mm, amount of Rutilus frisii kutum catches increased but amount of Mugil auratus catches decreased. No relationship was found between the length frequencies of two target fishes in two fishing cooperatives with height and mesh size (Table 5 and 6). Bycatch of fish were increased with an increase in the height of net. The most number of bycatch fishes belong to Clupeidae, Gobiidae and Acipenseridae, respectively (Fig. 4). The catches of pelagic species and inshore fish originating from beach seining are an important source of protein and contribute significantly to food security. The beach seine fishery also provides employment and a means of livelihood to most coastal

Table 1: Amount of catches $(\mathrm{kg})$ in Ghoreishi cooperative during sampling year of 2008 and 2009 using beach seine net with 20 and $24 \mathrm{~m}$ height and 30 and $33 \mathrm{~mm}$ mesh size net

\begin{tabular}{|c|c|c|}
\hline \multirow[b]{2}{*}{ Years (hight and mesh size) } & \multicolumn{2}{|c|}{ Amount per species } \\
\hline & $\begin{array}{l}\text { Rutilus frisii } \\
\text { kutum }\end{array}$ & Mugilauratus \\
\hline 2008 ( $20 \mathrm{~m}$ height and $30 \mathrm{~mm}$ mesh size $)$ & 1234 & 1508 \\
\hline 2008 ( $20 \mathrm{~m}$ height and $33 \mathrm{~mm}$ mesh size) & 7790 & 120 \\
\hline 2009 ( $24 \mathrm{~m}$ height and $30 \mathrm{~mm}$ mesh size $)$ & 1028 & 802 \\
\hline 2009 ( $24 \mathrm{~m}$ height and $33 \mathrm{~mm}$ mesh size) & 3225 & 62 \\
\hline
\end{tabular}

Table 2: Amount of catches $(\mathrm{kg})$ in Islami cooperative during sampling year of 2008 and 2009 using beach seine net with $24 \mathrm{~m}$ height with 30 and $33 \mathrm{~mm}$ mesh size net

\begin{tabular}{lcc}
\hline & Amount per species & \\
\cline { 2 - 3 } Years (mesh size) & Rutilus frisii kutum & Mugil curatus \\
\hline $2008(30 \mathrm{~mm})$ & 1805 & 1170 \\
$2008(33 \mathrm{~mm})$ & 11990 & 66 \\
$2009(30 \mathrm{~mm})$ & 2350 & 1203 \\
$2009(33 \mathrm{~mm})$ & 12538 & 68 \\
\hline
\end{tabular}

rural folks. It would be necessary to develop initiatives oriented towards maintaining equilibrium between the environmental and socio-economic dynamics of the communities to guarantee the sustainable use of the natural resources. Gear selectivity is a quantification of the varying probability of capture for different sizes and/or species of fish (Broadhurst et al., 2007; Backiel, 1980). Limited attempts were made to manage the beach activities in Iranian coast of the Caspian sea and involve height and mesh size regulation. Therefore in this

\begin{tabular}{lll}
\multicolumn{3}{l}{ Table 3: Analysis of catch data in Islami cooperative } \\
\hline Statistical tools & $\begin{array}{l}\text { Mugil curctus } \\
(2008 / 2009)\end{array}$ & $\begin{array}{l}\text { Rutilus frisii kutum } \\
(2008 / 2009)\end{array}$ \\
\hline 30 mm mesh size & & \\
Chi-square $\left(\chi^{2}\right)$ & 112.103 & 182.433 \\
df & 3 & 3 \\
p-value & 0.000 & 0.000 \\
33 mm mesh size & & \\
Chi-square $\left(\chi^{2}\right)$ & 7.169 & 10.498 \\
df & 2 & 2 \\
p-value & - & 0.005 \\
\hline
\end{tabular}

Table 4: Analy sis of catch data in Ghoreishi cooperative

\begin{tabular}{lll}
\hline Statistical tools & $\begin{array}{l}\text { Mugil curatus } \\
(2008 / 2009)\end{array}$ & $\begin{array}{l}\text { Rutilus frisii kutum } \\
(2008 / 2009)\end{array}$ \\
\hline 30 mm mesh size & & \\
Chi-square $\left(\chi^{2}\right)$ & 331.376 & 26.092 \\
df & 3 & 3 \\
p-value & 0.000 & 0.000 \\
33 mm mesh size & & \\
Chi-square $\left(\chi^{2}\right)$ & 18.601 & 791.076 \\
df & 2 & 2 \\
p-value & 0.000 & 0.000 \\
\hline
\end{tabular}

Table 5: Length (mean $\pm \mathrm{SD}$ ) of two target fishes in Islami Fishing cooperative caught during October to January (with $30 \mathrm{~mm}$ mesh size net) and during February to April (with $33 \mathrm{~mm}$ mesh size net)

\begin{tabular}{lcc}
\hline & \multicolumn{3}{c}{ Species } & \\
\cline { 2 - 3 } Months & Rutilus frisii kutum & Mugil curctus \\
\hline October & $41.08 \pm 5.87$ & $30.01 \pm 2.68$ \\
November & $37.49 \pm 6.44$ & $29.38 \pm 3.22$ \\
December & $38.86 \pm 4.38$ & $33.61 \pm 3.33$ \\
January & $39.52 \pm 5.16$ & $31.71 \pm 3.09$ \\
February & $43.17 \pm 4.20$ & $28.88 \pm 3.51$ \\
March & $44.57 \pm 3.18$ & $30.10 \pm 3.48$ \\
April & $45.00 \pm 3.48$ & $30.76 \pm 3.49$ \\
\hline
\end{tabular}

Table 6: Length (mean $\pm \mathrm{SD}$ ) of two target fishes in Ghoreishi fishing cooperative caught during October to January (with $30 \mathrm{~mm}$ mesh size net) and during February to April (with $33 \mathrm{~mm}$ mesh size net)

\begin{tabular}{lcc}
\hline & \multicolumn{2}{l}{ Species } \\
\cline { 2 - 3 } Months & Rutilus frisii kutum & Mugil auratus \\
\hline October & $40.82 \pm 5.23$ & $30.46 \pm 3.04$ \\
November & $40.15 \pm 5.17$ & $29.32 \pm 3.66$ \\
December & $39.81 \pm 6.50$ & $29.77 \pm 3.49$ \\
January & $40.36 \pm 5.01$ & $30.05 \pm 2.82$ \\
February & $42.77 \pm 4.22$ & $29.05 \pm 3.14$ \\
March & $44.01 \pm 3.89$ & $29.76 \pm 2.70$ \\
April & $43.81 \pm 3.61$ & $31.10 \pm 2.04$ \\
\hline
\end{tabular}




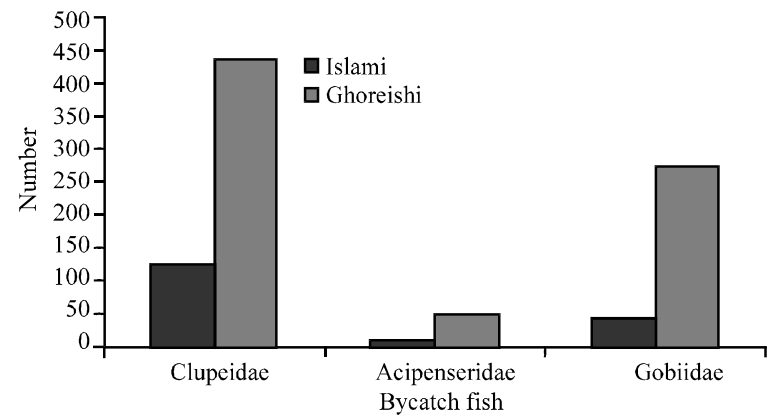

Fig. 4: No. of bycatch caught by nets used in Islami and Ghoreishi fishing cooperatives

study, we used two beach seines (Pareh) in order to identify and quantify the effect of nets with different height and mesh sizes on the catch species composition and catch rates in the Iranian coast of the Caspian sea. Because both cooperatives catch in same depth $(15 \mathrm{~m})$ and they located very close to each other, environmental conditions for both fishing cooperative were very similar. Therefore, decrease of catches in Ghoreishi fishing cooperative which used $24 \mathrm{~m}$ height net may be depended on the height of the net. Also, this reduction in the amount of catch may be due to decrease power of winches and hauling the net.

Study of Rutilus frisii kutum fish length showed that in Islami cooperative, number of fish with high length is more than Ghoreishi cooperative. But average of fish catch in relation with standard deviation shows that in some months, especially at the end of catching period length of fish in Islami cooperative is higher than Ghorashi cooperative. Anyway, analysis of length frequency showed that there is not any difference between two cooperatives. In fact, there is not any especial difference between two cooperative and it shows that increase of net height does not have any effect on fish length. Furthermore, Iranian Fisheries Research Organization introduced Rutilus frisii kutum $>30 \mathrm{~cm}$ and Mugil auratus $>28 \mathrm{~cm}$ fork length as standard fishes and fishermen must arrange their net to catch fishes bigger than standard size.

In Ghoreishi cooperative with increase in net height, the size of standard fishes was increased. Although, it is said that abundance generally declines exponentially with size both within and between species (Jennings et al., 2001). The amount of specimen (Rutilus frisii kutum) caught increased significantly when mesh size increased from $30-33 \mathrm{~mm}$ while the results showed adverse conditions for Mugil auratus as its amount declined. This was reflected in the rate of decline of the amount of individuals with mesh size being steeper for $30 \mathrm{~mm}$ than $33 \mathrm{~mm}$, however it depends on species and the size of fish. Previous studies have demonstrated that in some places the bycatch from beach seines can comprise up to $60 \%$ of the total catch and often includes large numbers of juveniles of economically-important species (Broadhurst et al., 2007). The potential mortality of these discarded individuals has raised serious concerns over the sustainability of beach seining at certain locations and led to investigations of modifications to conventional gears designed to reduce bycatch. Also, the observations show that with increase net height bycatch fishes were increased. The starting point for reducing bycatch in net based fishing gears like beach seines is to identify the strategic areas where most of the selection occurs and then regulate mesh openings at these areas according to the sizes of the main targeted species.

\section{CONCLUSION}

This study describes that attempts to regulate the beach seine activities have met with little success. To face this situation, decision making to seek support from the sustainable fisheries program would be useful. Thus the involvement of the fisheries communities in the process of setting up regulations for the use of the beach seine is an appropriate way, especially in regard to the decrease the cost of such experiments which may have some financial limitations for researchers. Proper management measures could include gear selectivity and mesh size regulation. Selective fishing methods should be encouraged which include standardization of height and mesh sizes in beach seine nets. Based on the results from this research, we found that the height and mesh sizes of beach seines may have an important influence on catch properties. However, more research must be done in this regards.

\section{ACKNOWLEDGEMENT}

The researchers finds it necessary to have especial thanks from Dr. Yaghmaei scientific staff of Golestan University for his assistance with this study.

\section{REFERENCES}

Abdolmaleki, S., G. Daryanabard and G. Bandani, 2005. Stock assessment of bony fishes in southern part of Caspian Sea. Aquaculture Research Institute, Sunndalsora, Norway.

Backiel, T., 1980. Introduction. In: Guidelines for Sampling Fish in Inland Waters, Backiel, T. and R.L. Welcomme, (Eds.). Food and Agriculture Organization of the United Nations, Rome. 
Broadhurst, M.K., M.E.L. Wooden and R.B. Millar, 2007. Isolating selection mechanisms in beach seines. Fish. Res., 88: 56-69.

Cailliet, G.M., M.S. Love and A.W. Ebeling, 1986. Fishes: A Field and Laboratory Manual on their Structure, Identification and Natural History. Wadsworth Publishing, Belmont, California, pp: 194.

Daryanabard, G., S. Abdolmaleki, G. Bandani and D. Kor, 2009. Stock Assessment of Bony Fishes of the Southern Part of Caspian Sea (2006-2008). Caspian Sea Ecological Research Institute, Northern Arizona.

$\mathrm{FAO}$, 2003. Strategies for increasing the sustainable contribution of small-scale fisheries to food security and poverty alleviation. FAO COFI/2003/9: 1-14.

Gabriel, O.K.L., E. Dahm and T. Wendt, 2005. Fish Catching Methods of the World. Blackwell Publishing Ltd., New York.

Ghaninejad, D. and M. Moghim, 1993. Stock Assessment of Bony Fishes of Caspian Sea. Giulan Fisheries Research Center, Iran.
Jennings, S., M.J. Kaiser and J.D. Reynolds, 2001. Marine Fisheries Ecology. Blackwell Science, Oxford, ISBN13: 978-0632050987, pp: 417.

Monteiro-Neto, C. and J.A. Musick, 1994. Effects of beach seine size on the assessment of surf-zone fish communities. Atlantica, 16: 23-29.

Murphy, B.R. and D.W. Willis, 1996. Fisheries Techniques. 2nd Edn., American Fisheries Society, Bethesda, Maryland.

Pierce, C.L., J.B. Rasmussen and W.C. Leggett, 1990. Sampling littoral fish with a seine: Corrections for variable capture efficiency. Can. J. Fish. Aquat. Sci., 47: 1004-1010.

Sayad, B.R., 1990. Analysis and Management of Economic and Bony Fishes of Caspian Sea. Giulan Fisheries Research Center, Iran.

Simon, T.P., 1998. Assessing the Sustainability and Biological Integrity of Water Resources using Fish Communities. CRC Press, Boca Raton, Florida.

Von Brandt, A., 1984. Fish Catching Methods of the World. 3rd Edn., Fishing News Book Ltd., UK., ISBN10: 0852381255, pp: 418. 